\title{
Frequêencia de Mutação no Códon 12 do Gene K-ras no Carcinoma Ductal Invasivo de Mama, Através da Técnica da Reação em Cadeia da Polimerase
}

\author{
Tese de Mestrado do Curso de Pós - Graduação da Faculdade de Ciências
} Médicas da Santa Casa de São Paulo, apresentada em 14/05/98

Autor: Sônia Maria Rolim Rosa Lima Orientador: Prof. Dr. Sebastião Piato

Introdução: Na carcinogênese mamária, ao lado de outras alterações gênicas, ocorre participação de oncogenes resultantes de mutações pontuais. O produto do proto-oncogene K-ras, a proteína Ras, localiza-se na face interna da membrana citoplasmática, tendo atuação central nos sinais de transdução do ciclo celular, na chamada cascata de fosforilação, responsável pela transmissão de sinais dos receptores tirosino-quinase ao núcleo. Quando ativado por mutação pontual, o oncogene resultante passa a dar origem a proteína Ras que sofre alterações em suas propriedades bioquímicas, perdendo a sua atividade GTAase normal, tornando-se permanentemente ligada à GTP. Como decorrência a proteína Ras permanece em sua configuração ativa, enviando sinais contínuos de transdução para o crescimento e diferenciação celular. Esta clonagem persistente caracteriza a fase de iniciação da carcinogênese.

Objetivo: Avaliar a freqüência de mutação no códon 12 do gene $\mathrm{K}$-ras no carcinoma ductal invasivo de mama, através da técnica de reação em cadeia da polimerase (PCR).

Material e Metodologia: Foram analisadas 50 amostras desparafinizadas de carcinoma ductal invasivo de mama, com $8 \mathrm{~m}$ de espessura. De cada amostra foi feita a extração do DNA com emprego da proteinase K. A amplificação de região específica de 157 pares de base, contendo o códon 12 do gene K-ras, foi realizada através de dupla PCR modificada por Levi e colaboradores, utilizando-se primers mismatches e análise do fragmento de comprimento variável, obtido através de clivagem por enzima de restrição Mva I. Graças a esta tecnologia obteve-se amplificação dos segmentos de pares de base normais e portadores de mutação. A constatação da presença ou não de mutação em cada amostra amplificada foi obtida através de eletroforese em gel de agarose a 0,8\%, utilizando-se marcador de peso molecular Ladder 123 (IBCO-BRL). A documentação fotográfica dos resultados foi feita com a utilização de luz ultra-violeta transmitida, empregando-se filme Polaroid tipo 667(ASA 3000).

Resultados: Em cinco dos 50 carcinomas de mama estudados (10\%), constatou-se a presença de mutação pontual no códon 12 do gene K-ras. Em todos os casos nos quais observou-se a referida mutação, as pacientes afetadas pelo carcinoma mamário encontravam-se na pós-menopausa. Em quatro dos casos o carcinoma mamário era moderadamente diferenciado (GII) e no restante era pouco diferenciado (GIII).

Palavras-chave: Oncogênese. Carcinogênese. Mama: câncer. Reação em Cadeia da Polimerase.

\section{Valor da Histerossonoğrafia na Avaliação da Cavidade Endometrial na Mulher com} Sangramento Uterino Anormal

Tese de Mestrado em Tocoginecologia da Faculdade de Ciências Médicas da Universidade Estadual de Campinas - UNICAMP, apresentada em 14/11/97.

Autor: Luiz Guilherme Trevisan de Albuquerque Orientador: Prof. Dra. Ellen Elizabeth Hardy

Sangramento uterino anormal é uma das queixas mais freqüentes das mulheres que procuram atenção ginecológica. Por este motivo, observa-se a necessidade de obter-se o diagnóstico de suas causas com métodos propedêuticos de fácil execução, de alta acurácia diagnóstica e de baixo custo. Esta pesquisa comparou a acurácia diagnóstica da histerossonografia com a da ultra-sonografia e histeroscopia no diagnóstico das alterações uterinas nas mulheres com história clínica de sangramento uterino anormal, tendo como padrão ouro a histologia. Foram examinadas 56 pacientes assistidas no Setor de Histeroscopia do CAISM/ UNICAMP e os resultados analisados, comparando a sensibilidade, especificidade, valores preditivos positivo e negativo dos três métodos propedêuticos. A sensibilidade da histerossonografia e da histeroscopia foi de $94 \%$ e a da ultra-sonografia foi de $83 \%$. A especificidade da histerossonografia foi de $87 \%$, da 